MELO, RAC; SILVA, GO; VENDRAME, LPC; PILON, L; GUIMARÃES, JA; AMARO, GB. 2020. Evaluation of purple-fleshed sweetpotato genotypes for root yield, quality and pest resistance. Horticultura Brasileira 38: 439-444. DOI: http://dx.doi.org/10.1590/s0102-0536202004016

\title{
Evaluation of purple-fleshed sweetpotato genotypes for root yield, quality and pest resistance
}

\author{
Raphael Augusto de C Melo ${ }^{1} \mathbb{D}$; Giovani Olegario da Silva ${ }^{1} \mathbb{D}$; Larissa PC Vendrame ${ }^{1} \mathbb{D}$; Lucimeire \\ Pilon ${ }^{1} \mathbb{D}$; Jorge Anderson Guimarães ${ }^{1} \mathbb{D}$; Geovani Bernardo Amaro ${ }^{1 \mathbb{D}}$
}

1Embrapa Hortaliças, Brasília-DF, Brasil; raphael.melo@embrapa.br; giovani.olegario@embrapa.br; larissa.vendrame@embrapa.br; lucimeire. pilon@embrapa.br; jorge.anderson@embrapa.br; geovani.amaro@embrapa.br

\begin{abstract}
Production of purple-fleshed sweetpotatoes, source of anthocyanins, pigments with high antioxidant activities, is expected to be extended during the upcoming years, as there is a strong trend to market products promising improved health. This study aimed to evaluate yield, postharvest quality and pest resistance of roots of purple-fleshed sweetpotatoes. Six genotypes (BGBD 0005, BGBD 0080, BGBD 1261, BGBD 1399, BGBD 1402 and BGBD 1405) and the cultivars Beauregard and Brazlândia Roxa as controls were evaluated during two seasons 2018 (Experiment 1) and 2019 (Experiment 2), in Brasília-DF, Brazil. The experiments were conducted in a complete randomized blocks design with four replications, with experimental plots consisting of two rows of six plants. Roots were harvested about 140 days after planting and evaluated for yield, appearance, insect damage and quality characteristics as soluble solids, dry matter and color. All genotypes showed roots with good resistance to soil insects. The highest commercial production of genotypes BGBD 1261, BGBD 0005, and BGBD 1405 associated to quality traits (dry matter content and soluble solids) and pest resistance, showed their potential for being released as cultivars or to be used in breeding programs.
\end{abstract}

Keywords: Ipomea batatas, marketable roots, appearance, insect damage, soluble solids, dry matter content.

\section{RESUMO}

Avaliação de genótipos de batata-doce de polpa roxa para produtividade de raízes, qualidade e resistência a insetos

A produção de batata-doce de polpa roxa, fonte de antocianinas, pigmentos com importantes propriedades antioxidantes, apresenta tendência de crescimento nos próximos anos, devido a um forte apelo de mercado para produtos que proporcionem benefícios à saúde. $\mathrm{O}$ objetivo deste estudo foi avaliar a produtividade, qualidade póscolheita e resistência a pragas de raízes de batata-doce de polpa roxa. Seis genótipos (BGBD005, BGBD080, BGBD1261, BGBD1399, BGBD1402 e BGBD1405) e duas cultivares testemunhas: Brazlândia Roxa e Beauregard, foram avaliados em dois experimentos nos anos agrícolas de 2018 (Experimento 1) e 2019 (Experimento 2), em Brasília-DF, Brasil. Os experimentos foram conduzidos no delineamento de blocos ao acaso com quatro repetições, com parcela útil experimental composta por duas linhas de seis plantas. Próximo dos 140 dias após os plantios, as raízes foram colhidas e avaliadas para produtividade de raízes, aparência, danos por insetos e caracteres de qualidade como sólidos solúveis, matéria seca e coloração. Pode-se verificar que todos os genótipos de polpa roxa avaliados apresentam bom padrão de resistência a danos por insetos de solo. A elevada produção comercial de raízes dos genótipos BGBD 1261, BGBD 0005 e BGBD 1405 associada a caracteres de qualidade (teor de matéria seca e sólidos solúveis) e de resistência a pragas, demonstrou o potencial para o seu lançamento como cultivares ou para utilização em programas de melhoramento genético.

Palavras-chave: Ipomoea batatas, raízes comerciais, aparência, danos por insetos, sólidos solúveis totais, matéria seca.

\section{Received on March 31, 2020; accepted on September 24, 2020}

$\mathrm{S}_{\mathrm{s}}^{\mathrm{v}}$ weetpotato (Ipomoea batatas) is one of the most important vegetables in Brazil and the social and economic significance of this crop can be attributed mainly to its rusticity, climatic adaptation and high capacity of production (Amaro et al., 2017, 2019).

A considerable genetic diversity of this species is observed in Brazil, originated by segregation and as a consequence of the introduction of plants from different places. This variability is also evident for the flesh colors, ranging from white, light yellow, yellow, orange, to purple (Ritschel \& Huamán, 2002; Silva et al., 2012; Carmona et al., 2015; Vargas et al., 2018). Purple-fleshed roots are rich in anthocyanins, a phenolic compound associated to reduction of the risk for a variety of degenerative diseases, due to its antioxidant activity (Reyes et al., 2005). In addition, sweetpotatoes are more affordable, easy to access and produced in large quantities per area when compared to other antioxidant foods (Mu et al., 2017). The diversity of foods with high levels of bioactive compounds available in the Brazilian market is high, but their affordability may be restricted to a portion of the population due to economic reasons. Fruits like blueberries, black plums or cherries are grown mainly in the subtropical region of the country, but mainly imported, which leads to 
high retail prices. Some vegetables and fruits, such as red onion, cabbage and table beet, açaí and black grapes can be considered exceptions, as they are widely distributed in the country. Thus purple-fleshed sweetpotatoes can become a year-round/feasible alternative to those species.

With proper management practices and adoption of technologies, yields can reach from $25 \mathrm{t} \mathrm{ha}^{-1}$ to $\geq 30 \mathrm{tha}^{-1}$ in 4 to 5 months (Andrade Júnior et al., 2012; Carmona et al., 2015; Amaro et al., 2019). The average national yield of sweetpotato of $14.5 \mathrm{t} \mathrm{ha}^{-1}$ (IBGE, 2019 ) is considered low, which can be attributed to the continuous use of slips or vines with systematic accumulation of diseases that cause their degeneration. Inadequate production systems and also low fertility soils result in genotypes/ cultivars not expressing their full genetic potential (Carmona et al., 2015, Melo et al., 2019). In Brazil, from the 29 sweetpotato cultivars registered in the RNC (National Cultivars Register), SCS370 Luiza is the only one with purple-flesh color (BRASIL, 2020), with restricted recommendation to Santa Catarina state and reported average yield of $14.7 \mathrm{t} \mathrm{ha}^{-1}$ (Schallenberger et al., 2017).

Therefore, the development of new purple-fleshed genotypes with higher root yield, quality and also pest resistance is needed. Many losses due to insect damages are reported, causing disposal or rejection by retailers and consumers (Ames et al., 1996; Edmunds et al., 2008; Moyer, 2018). The major pest species responsible for direct damages to sweetpotato roots in Brazil are Euscepes postfasciatus, Diabrotica speciosa, Diabrotica bivittula, Sternocolaspis quatuordecimcostata and Conoderus spp. (Gallo et al., 2002).

Chemical pesticides are not highly effective for controlling these pest species since they develop in the soil and are protected in the roots. Thus, their management should be focused on the cultural control and plant resistance. These management practices approaches combined with plant resistance of some genotypes (Collins et al., 1999) may be the most effective for pest control (Barreto et al., 2011; Andrade Junior et al., 2012; Massaroto et al., 2014).

Thus, in this study we aimed to evaluate yield, postharvest quality and pest resistance of roots of purple-fleshed sweetpotato genotypes.

\section{MATERIAL AND METHODS}

Two experiments were conducted at Embrapa Hortaliças $\left(15^{\circ} 56^{\prime} \mathrm{S}, 48^{\circ} 08^{\prime} \mathrm{W}\right.$, altitude $996 \mathrm{~m}$ ), Brasília-DF, Brazil. Planting dates were April 16, 2018 (Exp. 1), and February 07, 2019 (Exp. 2). During both periods of experimentation, maximum and minimum temperature, air humidity and accumulated rainfall were measured by an automatic weather station (INMET, 2020).

Six purple-fleshed sweetpotato genotypes (BGBD 0005, BGBD 0080, BGBD 1261, BGBD 1399, BGBD 1402 and BGBD 1405) were evaluated and, the cream-fleshed cultivar Brazlândia Roxa (Miranda, 1989) and orangefleshed cultivar Beauregard (Rolston et al., 1987) were used as controls. A complete randomized blocks design with four replications was used. Plots were composed of four rows with six plants each, spaced $0.80 \mathrm{~m}$ apart with $0.25 \mathrm{~m}$ between plants.

On both experiments, the preplant fertilization included $120 \mathrm{~kg} \mathrm{ha}^{-1}$ ammonium sulfate, $440 \mathrm{~kg} \mathrm{ha}^{-1}$ single superphosphate, $12 \mathrm{~kg} \mathrm{ha}^{-1}$ boric acid and $20 \mathrm{~kg} \mathrm{ha}^{-1}$ of ammonium zinc. Slips/ vines were transplanted 3 inches deep with 4 plant nodes underground, and 2 to 3 nodes above the ground. Weed control by hand-hoeing and topdress $\mathrm{N}$ fertilization $\left(50 \mathrm{~kg} \mathrm{ha}^{-1}\right)$ were performed 30 days after planting (DAP).

At 140 DAP (Exp. 1) and 138 DAP (Exp. 2), the center two rows of each plot were harvested and roots were evaluated for the following components of production: 1) number of commercial roots (CRN); 2) mass of commercial roots [CRM, $\left(\mathrm{t} \mathrm{ha}^{-1}\right)$ ]; 3) total number of roots (TRN); 4) total mass of roots [TRM ( $\left.\left.\mathrm{tha}^{-1}\right)\right]$; 5) $\mathrm{CRM} / \mathrm{CRN}$ ratio, in g. Appearance of roots (RA) was also evaluated, using visual index scores corresponding to: $1=$ non standards, with very irregular shape, large veins and cracks; $2=$ very nonuniform, with the presence of large veins and cracks; $3=$ nonuniform, with large veins and cracks; $4=$ slightly nonuniform with the presence of veins; and $5=$ regular fusiform without veins or cracks (Andrade Junior et al., 2012). Commercial roots were the ones with RA scores ranging from 4 to 5 and ID scores from 1 to 3 , and weighing between 150 and $1500 \mathrm{~g}$.

After sampling, 10 roots at random per plot, insects damage (ID) was evaluated with the index score as follow: $1=$ free of insect damage; $2=$ few damages; $3=$ few commercially damaged roots; $4=$ most commercially damaged roots; and $5=$ roots commercially unacceptable for both human and animal consumption (Massaroto et al., 2014).

The number of perforations (NP) per root, diameter (RD), length (RL) and skin thickness (ST), in mm, using a digital caliper, were also evaluated. The skin color (SC) was assessed by scores from: $1=$ white; $2=$ cream; $3=$ dark cream; $4=$ light yellow; $5=$ pink; $6=$ copper; $7=$ light purple; $8=$ dark purple; $9=$ reddish purple; and $10=$ purple. For the flesh color $(\mathrm{FC})$, scores were: $1=$ white; $2=$ cream; $3=$ dark cream; $4=$ light yellow; $5=$ yellow; $6=$ dark yellow; $7=$ orange; $8=$ light purple; $9=$ purple (Kalkmann, 2011).

Additionally, for the second experiment (Exp. 2), 10 roots were sampled randomly in each plot and evaluated for dry matter [DM (\%)] and soluble solids (SS) content. Each genotype had its flesh crushed and the liquid portion was used to determine SS in a digital refractometer (PR-101, Atago Co. Ltda., Tokyo, Japan). Results were expressed in ${ }^{\circ}$ Brix (AOAC, 2005). $\mathrm{DM}$ was determined by weighing the samples $(5 \mathrm{~g})$ before and after drying in an oven (Quimis, São Paulo-SP, Brazil) at $105^{\circ} \mathrm{C}$ for $3 \mathrm{~h}$. Petri dishes were cooled in a desiccator until room temperature and then weighted. This procedure was repeated until constant samples weight (Quimis, São Paulo-SP, Brazil). DM was calculated according to the following equation: DM\% = dry weight $(\mathrm{g}) /$ fresh weight $(\mathrm{g}) \times 100$.

Data were tested for normal distribution by Lilliefors test and submitted to analysis of individual and combined variance for the two periods 
of experiments, and cluster means were compared by Scott-Knott grouping test at 5\%. All statistical analyses were performed using Genes software (Cruz, 2013) and AgroEstat (Barbosa \& Maldonado Júnior, 2015).

\section{RESULTS AND DISCUSSION}

The analysis of variance showed that there was an interaction between the two periods of experimentation and genotypes for CRN (commercial root number), CRM (commercial root mass), TRN (total root number), TRM (total root mass), $\mathrm{CRM} / \mathrm{CRN}$ ratio, $\mathrm{RA}$ (root appearance), ID (insect damage),
SC (skin color) and FC (flesh color). NP (number of perforations) showed a higher CV of $68.67 \%$; however, its relation of genetic and phenotypic coefficient $(\mathrm{CVg} / \mathrm{CV})$ was greater than one, denoting a predominance of genetic variance, making possible to use this information to select the best genotypes (Table 1 and 2).

In Exp. 1, the BGBD 1261 genotype showed the highest CRM (51.11 $\left.\mathrm{t} \mathrm{ha}^{-1}\right)$ followed by BGBD 0005 (36.25 $\left.\mathrm{t} \mathrm{ha}^{-1}\right)$, BGBD 1402 (35.38 t ha-1), Beauregard (28.18 $\mathrm{t} \mathrm{ha}^{-1}$ ) and Brazlândia Roxa (35.46 $\mathrm{t} \mathrm{ha}^{-1}$ ). In Exp. 2, Beauregard had the highest CRM, (35.68 $\left.\mathrm{tha}^{-1}\right)$. The higher CRM during Exp. 1 values may be associated with cooler temperatures and a better distribution of rainfall, presenting an average maximum temperature of $27.18^{\circ} \mathrm{C}$, minimum of $17.63^{\circ} \mathrm{C}$, air humidity of $73.2 \%$ and accumulated rainfall of $964.2 \mathrm{~mm}$. The aforementioned weather conditions meet the requirements of sweetpotatoes and possibly lead to a good vine/ root ratio (Lebot, 2019). As for Exp. 2 , an average maximum temperature of $21.8^{\circ} \mathrm{C}$, minimum of $20.63^{\circ} \mathrm{C}$ and air humidity of $41.5 \%$, associated to lower values of rainfall (accumulated $185 \mathrm{~mm}$ ), with no registered values for June, July and only $10 \mathrm{~mm}$ during August, may possibly have impacted the obtained CRM.

The average CRM of the genotypes,

Table 1. CRN (number of commercial root $\mathrm{x} 10^{3} \mathrm{ha}^{-1}$ ), CRM (mass of commercial root, in $\mathrm{t} \mathrm{ha}^{-1}$ ), TRN (total number of root $\mathrm{x} 10^{3}$ ha ${ }^{-1}$ ), TRM (total mass of root, in $\mathrm{t} \mathrm{ha}^{-1}$ ), CRM/CRN ratio, in g, and RA (root appearance) of eight purple-fleshed sweetpotato genotypes evaluated in 2018 and 2019. Brasília, Embrapa Hortaliças, 2018-2019.

\begin{tabular}{|c|c|c|c|c|c|c|}
\hline \multirow{2}{*}{ Genotypes } & \multicolumn{2}{|c|}{ CRN } & \multicolumn{2}{|c|}{ CRM } & \multicolumn{2}{|c|}{ TRN } \\
\hline & 2018 & 2019 & 2018 & 2019 & 2018 & 2019 \\
\hline BGBD 0005 & $166.67 \mathrm{aA}$ & $60.42 \mathrm{bB}$ & $36.25 \mathrm{bA}$ & $10.79 \mathrm{bB}$ & $411.46 \mathrm{aA}$ & $246.25 \mathrm{aB}$ \\
\hline BGBD 0080 & $86.46 \mathrm{bA}$ & $56.82 \mathrm{bA}$ & $18.35 \mathrm{cA}$ & $25.03 \mathrm{bA}$ & $403.13 \mathrm{aA}$ & $197.16 \mathrm{aB}$ \\
\hline BGBD 1261 & $148.96 \mathrm{aA}$ & $69.61 \mathrm{bB}$ & $51.11 \mathrm{aA}$ & $18.79 \mathrm{bB}$ & $272.92 \mathrm{bA}$ & $217.61 \mathrm{aA}$ \\
\hline BGBD 1399 & $43.75 \mathrm{cA}$ & $59.75 \mathrm{bA}$ & $9.37 \mathrm{cB}$ & $22.40 \mathrm{bA}$ & $272.92 \mathrm{bA}$ & $258.71 \mathrm{aA}$ \\
\hline BGBD 1402 & $139.38 \mathrm{aA}$ & $69.21 \mathrm{bB}$ & $35.38 \mathrm{bA}$ & $16.84 \mathrm{bB}$ & $435.21 \mathrm{aA}$ & $208.85 \mathrm{aB}$ \\
\hline BGBD 1405 & $99.06 \mathrm{bA}$ & $94.02 \mathrm{aA}$ & $19.49 \mathrm{cA}$ & $21.22 \mathrm{bA}$ & $380.49 \mathrm{aA}$ & $201.97 \mathrm{aB}$ \\
\hline Beauregard & $97.24 \mathrm{bA}$ & $94.74 \mathrm{aA}$ & $28.18 \mathrm{bA}$ & $35.68 \mathrm{aA}$ & $402.44 \mathrm{aA}$ & $230.42 \mathrm{aB}$ \\
\hline Braz. Roxa & $139.59 \mathrm{aA}$ & $74.87 \mathrm{bB}$ & $35.46 \mathrm{bA}$ & $14.75 \mathrm{bB}$ & $290.63 \mathrm{bA}$ & $264.83 \mathrm{aA}$ \\
\hline Means & $115.14 \mathrm{~A}$ & $72.43 \mathrm{~B}$ & $29.20 \mathrm{~A}$ & $20.69 \mathrm{~A}$ & $358.65 \mathrm{~A}$ & $228.22 B$ \\
\hline CV (\%) & 25.77 & 23.10 & 29.65 & 30.79 & 21.22 & 24.36 \\
\hline \multirow[t]{3}{*}{$\mathrm{CVg} / \mathrm{CV}$} & 1.27 & 0.73 & 1.44 & 1.07 & 0.74 & 0.01 \\
\hline & \multicolumn{2}{|c|}{ TRM } & \multicolumn{2}{|c|}{ CRM/CRN ratio } & \multicolumn{2}{|c|}{$\mathbf{R A}$} \\
\hline & 2018 & 2019 & 2018 & 2019 & 2018 & 2019 \\
\hline BGBD 0005 & $49.57 \mathrm{bA}$ & $22.57 \mathrm{bB}$ & $218.13 \mathrm{aA}$ & $179.95 \mathrm{bA}$ & $4.00 \mathrm{aA}$ & $4.25 \mathrm{aA}$ \\
\hline BGBD 0080 & $33.83 \mathrm{cA}$ & $38.79 \mathrm{aA}$ & $215.68 \mathrm{aB}$ & $490.95 \mathrm{aA}$ & $3.00 \mathrm{bA}$ & $2.50 \mathrm{bA}$ \\
\hline BGBD 1261 & $68.40 \mathrm{aA}$ & $28.25 \mathrm{bB}$ & $344.10 \mathrm{aA}$ & $267.51 \mathrm{bA}$ & $3.00 \mathrm{bA}$ & $2.50 \mathrm{bA}$ \\
\hline BGBD 1399 & $20.22 \mathrm{~dB}$ & $37.63 \mathrm{aA}$ & $195.56 \mathrm{aB}$ & $399.86 \mathrm{aA}$ & $2.50 \mathrm{cB}$ & $3.25 \mathrm{bA}$ \\
\hline BGBD 1402 & $51.76 \mathrm{bA}$ & $32.43 \mathrm{bB}$ & $254.38 \mathrm{aA}$ & $250.29 \mathrm{bA}$ & $3.00 \mathrm{bA}$ & $3.50 \mathrm{bA}$ \\
\hline BGBD 1405 & $36.83 \mathrm{cA}$ & $29.49 \mathrm{bA}$ & $221.30 \mathrm{aA}$ & $217.81 \mathrm{bA}$ & $3.00 \mathrm{bB}$ & $4.25 \mathrm{aA}$ \\
\hline Beauregard & $47.35 \mathrm{bA}$ & $50.54 \mathrm{aA}$ & $271.33 \mathrm{aA}$ & $371.59 \mathrm{aA}$ & $1.00 \mathrm{~dB}$ & $5.25 \mathrm{aA}$ \\
\hline Braz. Roxa & $44.70 \mathrm{bA}$ & $27.31 \mathrm{bB}$ & $253.65 \mathrm{aA}$ & $207.59 \mathrm{bA}$ & $4.00 \mathrm{aA}$ & $3.25 \mathrm{bB}$ \\
\hline Means & $44.08 \mathrm{~A}$ & $33.37 \mathrm{~A}$ & $246.77 \mathrm{~A}$ & $298.19 \mathrm{~A}$ & $2.94 \mathrm{~A}$ & $3.59 \mathrm{~A}$ \\
\hline CV (\%) & 23.20 & 28.82 & 22.91 & 35.99 & 6.95 & 21.81 \\
\hline $\mathrm{CVg} / \mathrm{CV}$ & 1.30 & 0.76 & 0.66 & 0.90 & 4.59 & 1.10 \\
\hline
\end{tabular}

RA scores: $1=$ nonstandards, with very irregular shape, large veins and cracks; $2=$ very nonuniform, with the presence of large veins and cracks; $3=$ nonuniform, with large veins and cracks; $4=$ slightly nonuniform with the presence of veins, and 5= regular fusiform without veins or cracks. $\mathrm{CV}(\%)=$ phenotypic coefficient of variation; $\mathrm{CVg} / \mathrm{CV}=$ genotypic and phenotypic coefficient of variation ratio. Means followed by the same lowercase letter in the column and uppercase in the line do not differ using the least significant difference values of $\leq 0.5 \%$ by Scott-Knott grouping test. 
Table 2. RD (root diameter, in mm), SC (skin color), FC (flesh color), NP (number of insect perforations), ID (insect damage), RL (root length, in mm), ST (skin thickness, in $\mathrm{mm}$ ), DM (dry matter in \%) and SS (soluble solids in ${ }^{\circ}$ Brix) of eight purple-fleshed sweetpotato genotypes evaluated in 2018 and 2019. Brasília, Embrapa Hortaliças, 2018-2019.

\begin{tabular}{|c|c|c|c|c|c|c|}
\hline \multirow{2}{*}{ Genotypes } & \multicolumn{2}{|c|}{ RD } & \multicolumn{2}{|c|}{ SC } & \multicolumn{2}{|c|}{ FC } \\
\hline & 2018 & 2019 & 2018 & 2019 & 2018 & 2019 \\
\hline BGBD 0005 & $49.18 \mathrm{aA}$ & $49.04 \mathrm{aA}$ & $9.00 \mathrm{aA}$ & $7.00 \mathrm{~dB}$ & $8.00 \mathrm{aA}$ & $8.00 \mathrm{bA}$ \\
\hline BGBD 0080 & $44.80 \mathrm{bA}$ & $50.25 \mathrm{aA}$ & $8.75 \mathrm{aA}$ & $7.00 \mathrm{~dB}$ & $8.00 \mathrm{aA}$ & $8.00 \mathrm{bA}$ \\
\hline BGBD 1261 & $55.36 \mathrm{aA}$ & $55.86 \mathrm{aA}$ & $9.00 \mathrm{aA}$ & $7.50 \mathrm{cB}$ & $8.00 \mathrm{aA}$ & $8.00 \mathrm{bA}$ \\
\hline BGBD 1399 & $36.96 \mathrm{bB}$ & $44.09 \mathrm{bA}$ & $9.00 \mathrm{aA}$ & $9.00 \mathrm{aA}$ & $9.00 \mathrm{aA}$ & $9.00 \mathrm{aA}$ \\
\hline BGBD 1402 & $56.57 \mathrm{aA}$ & $53.00 \mathrm{aA}$ & $7.00 \mathrm{bB}$ & $8.00 \mathrm{bA}$ & $8.00 \mathrm{aA}$ & $8.00 \mathrm{bA}$ \\
\hline BGBD 1405 & $43.14 \mathrm{bA}$ & $36.43 \mathrm{cA}$ & $7.00 \mathrm{bA}$ & $7.00 \mathrm{dA}$ & $8.00 \mathrm{aA}$ & $8.75 \mathrm{aA}$ \\
\hline Beauregard & $57.05 \mathrm{aA}$ & $46.13 \mathrm{bB}$ & $5.00 \mathrm{cB}$ & $6.00 \mathrm{eA}$ & $7.00 \mathrm{aA}$ & $7.00 \mathrm{cA}$ \\
\hline Braz. Roxa & - & $46.12 \mathrm{~b}$ & - & $5.25 \mathrm{f}$ & - & $2.00 \mathrm{~d}$ \\
\hline Means & $49.01 \mathrm{~A}$ & $41.59 \mathrm{~A}$ & $7.82 \mathrm{~A}$ & $7.35 \mathrm{~A}$ & $8.00 \mathrm{~A}$ & $8.53 \mathrm{~A}$ \\
\hline CV (\%) & 11.89 & 47.05 & 2.42 & 7.09 & 0.00 & 7.34 \\
\hline \multirow[t]{3}{*}{$\mathrm{CVg} / \mathrm{CV}$} & 1.23 & 8.86 & 8.16 & 3.96 & 0.00 & 2.41 \\
\hline & \multicolumn{4}{|c|}{2018 and 2019} & \multicolumn{2}{|c|}{2019} \\
\hline & $\mathbf{N P}$ & ID & $\mathbf{R L}$ & ST & DM & SS \\
\hline BGBD 0005 & $4.30 \mathrm{~b}$ & $2.03 \mathrm{~b}$ & $177.03 \mathrm{a}$ & $3.82 \mathrm{a}$ & $29.55 \mathrm{~d}$ & $9.55 \mathrm{c}$ \\
\hline BGBD 0080 & $2.51 \mathrm{~b}$ & $1.75 \mathrm{~b}$ & $132.72 \mathrm{a}$ & $1.92 \mathrm{a}$ & $31.04 \mathrm{c}$ & $10.33 \mathrm{~b}$ \\
\hline BGBD 1261 & $7.67 \mathrm{~b}$ & $2.05 \mathrm{~b}$ & $178.67 \mathrm{a}$ & $1.38 \mathrm{a}$ & $31.99 \mathrm{c}$ & $10.45 \mathrm{~b}$ \\
\hline BGBD 1399 & $4.89 \mathrm{~b}$ & $1.76 \mathrm{~b}$ & $166.02 \mathrm{a}$ & $1.93 \mathrm{a}$ & $35.42 \mathrm{~b}$ & $10.50 \mathrm{~b}$ \\
\hline BGBD 1402 & $6.05 \mathrm{~b}$ & $1.98 \mathrm{~b}$ & $133.99 \mathrm{a}$ & $3.61 \mathrm{a}$ & $29.31 \mathrm{~d}$ & $8.85 \mathrm{c}$ \\
\hline BGBD 1405 & $5.88 \mathrm{~b}$ & $2.16 \mathrm{~b}$ & $158.07 \mathrm{a}$ & $2.77 \mathrm{a}$ & $35.07 \mathrm{~b}$ & $11.90 \mathrm{a}$ \\
\hline Beauregard & $24.75 \mathrm{a}$ & $3.15 \mathrm{a}$ & $150.79 \mathrm{a}$ & $2.02 \mathrm{a}$ & $39.48 \mathrm{a}$ & $10.58 \mathrm{~b}$ \\
\hline Braz. Roxa & $4.27 \mathrm{~b}$ & $1.97 \mathrm{~b}$ & $174.10 \mathrm{a}$ & $2.65 \mathrm{a}$ & $22.19 \mathrm{e}$ & $9.25 \mathrm{c}$ \\
\hline Means & 8.01 & 2.12 & 156.76 & 2.49 & 31.75 & 10.18 \\
\hline CV (\%) & 68.67 & 19.20 & 13.30 & 18.20 & 16.23 & 8.36 \\
\hline $\mathrm{CVg} / \mathrm{CV}$ & 1.32 & 1.24 & 0.01 & 0.52 & 6.87 & 1.00 \\
\hline
\end{tabular}

SC scores: $1=$ white; $2=$ cream; $3=$ dark cream; $4=$ light yellow; $5=$ pink; $6=$ copper; $7=$ light purple; $8=$ dark purple; $9=$ reddish purple, and $10=$ purple. FC scores: $1=$ white; $2=$ cream; $3=$ dark cream; $4=$ light yellow; $5=$ yellow; $6=$ dark yellow; $7=$ orange; $8=$ light purple; $9=$ purple. ID scores: $1=$ free of insect damage; $2=$ few damages; $3=$ few commercially damaged roots; $4=$ most commercially damaged roots, and $5=$ roots commercially unacceptable. $\mathrm{CV}(\%)=$ phenotypic coefficient of variation; $\mathrm{CVg} / \mathrm{CV}=$ genotypic and phenotypic coefficient of variation ratio. Means followed by the same lowercase letter in the column and uppercase in the line do not differ using the least significant difference values of $\leq 0.5 \%$ by Scott-Knott grouping test.

considering the 2018 and 2019 seasons, is equivalent or higher than the CRM of purple-fleshed genotypes grown in different countries (Nwosisi et al., 2017; Musabyemungu et al., 2019), and much higher than the average Brazilian yield (14.51 t ha ${ }^{-1}$ ) (IBGE, 2019). In Exp. 1, BGBD 0005, BGBD 1261, BGBD 1402 and Brazlândia Roxa had the highest CRN; and in Exp. 2, the genotypes with the highest CRN were BGBD 1405 and Beauregard (Table 1).

The genotypes BGBD 1261 , BGBD 0005, BGBD 1402, Beauregard and Brazlândia Roxa showed quite satisfactory CRN and CRM in both seasons, demonstrating their potential for root mass production. In Exp. 1, for the $\mathrm{CRM} / \mathrm{CRN}$ ratio, no differences were found between the genotypes, with mean value of 246.77 g. In Exp. 2, BGBD 0080 (490.95 g), BGBD 1399 (399.86 g) and Beauregard (371.59 g) showed the highest CRM/CRN ratio (Table 1). Except for the BGBD 0080 roots in Exp. 2, the other genotypes would be graded as $2 \mathrm{~A}$ according to Brazilian standards for grades of sweetpotatoes, ranging in weight from 150 to $450 \mathrm{~g}$, which is most profitable for growers (CEAGESP, 2017).

In Exp. 1 BGBD 0005 and
Brazlândia Roxa had the most suitable appearance of roots with the highest scores. In Exp. 2, BGBD 0005, BGBG 1405, and Beauregard showed the highest scores (Table 1). Appearance is considered the most influential sweetpotatoes attribute considered during their purchase decision-making process. Colored flesh cultivars are well accepted by consumers, as long as added to other attributes such as flavor and texture (Leksrisompong et al., 2012).

Beauregard was less resistant to pest attack (predominantly Euscepes postfasciatus). This cultivar showed higher NP and ID scores than all 
genotypes and Brazlândia Roxa (Table $2)$. The fact that the purple-fleshed genotypes have grouped with Brazlândia Roxa (Table 2) may be an indicative of their resistance to pests since this cultivar is considered insect-resistant (Barreto et al., 2011; Andrade Junior et al., 2012; Massaroto et al., 2014; Amaro et al., 2019).

Roots of purple-fleshed sweetpotatoes did not differ in length (RL) in both seasons (Table 2). Regarding the diameter (RD), in both 2018 and 2019 seasons, BGBD 0005, BGBD 1261 and BGBD 1402 showed the highest $\mathrm{RD}$ (Table 2). These genotypes showed no difference from Beauregard in 2018 and BGBD 0080 in 2019. Fusiformshaped sweetpotato is the most accepted for fresh commercialization (Andrade Junior et al., 2012). As the purplefleshed genotypes had similar lengths (mean value of $156.76 \mathrm{~mm}$ ), those with a larger diameter (about $55 \mathrm{~mm}$ ) (Table 2) could be considered to have the best shape, with a ratio close to $1 / 3$ of the diameter by length. Based on this standard, the best genotypes coincide with those with higher CRM (Table 1).

Skin thickness (ST), was similar for all genotypes, with a mean value of $2.49 \mathrm{~mm}$ (Table 2). Roots of freshly harvested sweetpotato have a thin skin and therefore susceptible to mechanical damage (Edmunds et al., 2008). Thus, genotypes with thicker skin, which do not damage when washed and classified, are more recommended (Edmunds $e t$ al., 2008).

BGBD 1399 genotype showed an intense purple color and best scored for SC in Exp. 2, and in Exp. 1 this genotype was similar to BGBD 0005, BGBD 0080 and BGBD 1261 (Table 2). The genotypes BGBD 1399 and BGBD 1405 showed the highest score for FC in Exp. 2 (Table 2), which may be an indicative of higher anthocyanin content. All other genotypes showed FC scores classified as light purple.

BGBD 1399 and BGBD 1405 showed $35.42 \%$ and $35.07 \%$ dry matter (DM), respectively (Table 2). These contents were higher than those found for Beauregard (22.19\%) and lower than those of Brazlândia Roxa (39.48\%). $\mathrm{DM}$ is an important quality attribute, especially for the production of flour, chips and other processed products, to maximize yield and to minimize oil or drying costs. Some cultivars adopted by the industry have DM around 30\% (Mosta et al., 2015; Marangoni Junior, 2017). BGBD 1405 genotype also showed the highest SS contents, followed by BGBD 0080, BGBD 1261, BGBD 1399, and Beauregard (Table 2). Soluble solids mainly express the sugar content and may be related to a better flavor (Chitarra \& Chitarra, 2005) and the contents found for the genotypes correspond to those found for other cultivars (Mu et al., 2017; Vizzotto et al., 2017; Sugri et al., 2019). SS is also an important quality character related to consumer's preferences. The six purplefleshed genotypes evaluated showed similar SS values as 10 genotypes studied by Oliveira et al. (2019). BGBD 1405 with $11.90^{\circ}$ Brix, value in close proximity to a purple-fleshed genotype named UGA-34, showed $13^{\circ}$ Brix in the aforementioned study, an indication of higher sucrose content, which can increase its acceptability.

The roots of all evaluated genotypes showed good levels of pest resistance, similarly to other purple-fleshed cultivars, such as Okinawan, which was described in Hawaii as having some resistance (Miyasaka et al., 2019).

This result is an important indicator of the substantial root commercial production of genotypes BGBD 1261, BGBD 0005, and BGBD 1405 associated to quality traits (dry matter content and soluble solids) and pest resistance, which showed their potential for being released as cultivars or to be used in breeding programs.

\section{REFERENCES}

AMARO, GB; FERNANDES, FR; SILVA, GO; MELLO, AFS; CASTRO, LAS. 2017. Desempenho de cultivares de batata doce na região do Alto Paranaíba-MG. Horticultura Brasileira 35: 286-291.

AMARO, GB; TALAMINI, V; FERNANDES, FR; SILVA, GO; MADEIRA, NR. 2019. Desempenho de cultivares de batata-doce para rendimento e qualidade de raízes em Sergipe. Revista Brasileira de Ciências Agrárias 14: e5628.

AMES, T; SMIT, NEJM; BRAUN, AR;
O'SULLIVAN, JN; SKOGLUND, LG. 1996. Sweet potato: major pests, diseases, and nutritional disorders. Lima: International Potato Center, 152p.

ANDRADE JUNIOR, VC; VIANA, DJS; PINTO, NAVD; RIBEIRO, KG; PEREIRA, RC; NEIVA, IP; AZEVEDO, AM; ANDRADE, PCR. 2012. Características produtivas e qualitativas de ramas e raízes de batata-doce. Horticultura Brasileira 30: 584-589.

AOAC - Association of Official Analytical Chemists. 2005. Official methods of analysis. $16^{\text {th }}$ ed. Gaithersburg, Maryland: AOAC.

BARBOSA, JC; MALDONADO, JUNIOR, W. 2015. AgroEstat - sistema para análises estatísticas de ensaios agronômicos. Jaboticabal: FCAV/UNESP. 396p.

BARRETO, HG; SANTOS, LB; OLIVEIRA, GÍS; SANTOS, GR; FIDELIS, RR; SILVEIRA, MA; NASCIMENTO, IR. 2011. Estabilidade e adaptabilidade da produtividade e da reação a insetos de solo em genótipos experimentais e comerciais de batata-doce. Bioscience Journal 27: 739-747.

BRASIL. Registro Nacional de cultivares. 2020. Brasília. Available at <http://extranet. agricultura.gov.br/php/snpc/cultivarweb/ cultivares_registradas.php $>$. Accessed on February $\overline{12}, 2020$.

CARMONA, PAO; PEIXOTO, JR; AMARO, GB; MENDONÇA, MA. 2015. Divergência genética entre acessos de batata-doce utilizando descritores morfoagronômicos das raízes. Horticultura Brasileira 33: 241-250. Available at https://doi.org/10.1590/S0102053620150000200017

CEAGESP - Companhia de Entrepostos e Armazéns Gerais de São Paulo. Centro de Qualidade, Pesquisa e Desenvolvimento. 2017. Cartilha Técnica: a medida das hortaliças. São Paulo: 16p.

CHITARRA, MIF; CHITARRA, AB. 2005. Póscolheita de frutos e hortaliças: fisiologia e manuseio. 2. ed., Lavras: UFLA. 785p.

COLLINS, WW; CAREY, EE; MOK, IG; THOMPSON, P; ZHANG, DP. 1999. Utilization of sweetpotato genetic resources to develop insect resistance. In: CLEMENT, SL; QUISENBERRY, SS (ed). Global genetic resources for insect-resistance crops. Florida: CRC Press, p.193-205.

CRUZ, CD. 2013. Genes: a software package for analysis in experimental statistics and quantitative genetics. Acta Scientiarum Agronomy 35: 271-276.

EDMUNDS, B; BOYETTE, M; CLARK, C; FERRIN, D; SMITH, T; HOLMES, G. 2008. Postharvest handling of sweetpotatoes. NC Cooperative extension Service. AG-413-10B. $56 \mathrm{p}$.

GALLO, D. et al. 2002. Batata-doce: Ipomoea batatas Lam. In: GALLO, D. et al. (eds). Entomologia agrícola. Piracicaba: FEALQ, p.522-524. (Biblioteca de Ciências Agrárias Luiz de Queiroz, 10).

IBGE - Instituto Brasileiro de Geografia e Estatística. 2019. Produção Agrícola Municipal: informações sobre culturas temporárias. Rio de Janeiro: IBGE. Available at <http://www.sidra.ibge.gov.br/bda/ 
pesquisas/pam/default.asp $>$. Accessed August 21, 2019.

INMET - Instituto Nacional de Meteorologia. 2020. Available at $<$ http://www.inmet. gov.br/sonabra/pg_dspDadosCodigo_sim. php?QTA0Ng>. Accessed June, 2020.

KALKMANN, DC. 2011. Produtividade, qualidade da raiz, resistência aos insetos de solo e aos nematoides-das-galhas, e estimativas de parâmetros genéticos em clones de batata-doce cultivados no Distrito Federal. Brasília: UnB. 144p. (M.Sc. Dissertation).

LEBOT, V. 2019. Developmental physiology. In: Tropical root and tuber crops - cassava, sweet potato, yams and aroids. Wallingford: CABI. p144-154.

LEKSRISOMPONG, PP; WHITSON, ME; TRUONG, VD; DRAKE, MA. 2012. Sensory attributes and consumer acceptance of sweet potato cultivars with varying flesh colors. Journal of Sensory Studies 27: 59-69.

MARANGONI JÚNIOR, L. 2017. Chips de batata-doce biofortificada: desenvolvimento do produto e estudo de estabilidade em diferentes sistemas de embalagem. Campinas: ITAL. 119p. (M.Sc. Dissertation).

MASSAROTO, JA; MALUF, WR; GOMES, LAA; FRANCO, HD; GASPARINO, CF. 2014. Desempenho de clones de batata-doce. Ambiência 10: 73-81.

MELO, RAC; AMARO, GB; VENDRAME, LPC; PILON, L. 2019. Produtividade de batata-doce em canteiros utilizando diferentes espaçamentos e segmentos da rama. Brasília: Embrapa Hortaliças (Boletim de pesquisa e desenvolvimento, 199). 20p.

MIRANDA, JEC. 1989. Brazlândia Roxa, Brazlândia Branca; Brazlândia Rosada e Coquinho: novas cultivares de batata-doce.
Horticultura Brasileira 7: 32-33.

MIYASAKA, S; WALL, M; LABONTE, D; ARAKAKI, A. 2019. Sweetpotato cultivar trials on Hawai' $i$ island. HortTechnology. 1-9. 10.21273/HORTTECH04387-19.

MOSTA, NM; MODI, AT; MABHAUDHI, T. 2015. Sweet potato (Ipomoea batatas L.) as a drought tolerant and food security crop. South African Journal of Science 111: 1-8.

MOYER, JW. 2018. Major disease pests. In: Sweet potato products: A natural resource for the tropics. BOUWKAMP, JC (ed).Boca Raton: CRC Press. p.35-58.

MU, T; SUN, H; ZHANG, M; WANG, C. 2017. Sweetpotato anthocyanins. In: Sweetpotato Processing Technology. In: MU, T; SUN, H; ZHANG, M; WANG, C (eds). p.279-355.

MUSABYEMUNGU, A; WASSWA, P; ALAJO, A; CHELAGAT, D; OTEMA, M; MUSANA, P; RUKUNDO, P; GIBSON, P; EDEMA, R; PECOTA, K; YENCHO, C; YADA, B. 2019. Adaptability of a U.S. purple-fleshed sweetpotato breeding population in Uganda. Australian Journal of Crop Science 13: 17-25.

NWOSISI, S; NANDWANI, D; POKHAREL, B. 2017. Yield performance of organic sweetpotato varieties in various mulches. Horticulturae 3: 48-58.

OLIVEIRA, AF; MACHADO SOARES, J; SILVA, EC; LOUBET FILHO, PS; JORDÃO CANDIDO, C; AMARAL, LA; NOVELLO, D. 2019. Evaluation of the chemical, physical and nutritional composition and sensory acceptability of different sweet potato cultivars. Ciências Agrárias, 40: 1127-1113.

REYES, LF; MILLER, JR; CISNEROSZEVALLOS, L. 2005. Antioxidant capacity, anthocyanins and total phenolics in purpleand red-fleshed potato (Solanum tuberosum
L.) genotypes. American Journal of Potato Research 82: 271-277.

RITSCHEL, OS; HUÁMAN, Z. 2002. Variabilidade morfológica da coleção de germoplasma de batata-doce da Embrapa Centro Nacional de Pesquisas de Hortaliças. Pesquisa Agropecuária Brasileira 37: 485492.

ROLSTON, LH; CLARK, CA; CANNON, JM; RANDLE, WM; RILEY EG; WILSON, PW; ROBBINS, ML. 1987. 'Beauregard' sweet potato. HortScience 22: 1338-1339.

SCHALLENBERGER, E; REBELO, JA; CANTÚ, RR; MORALES, RGF; CARMINATTI, R; PORCU, OM; WAMSER, GH. 2017. Novas cultivares de batata-doce: SCS370 Luiza, SCS371 Katiy, SCS372 Marina. Agropecuária Catarinense 30: 43-47.

SILVA, GO; PONIJALEKI, R; SUINAGA, FA. 2012. Divergência genética entre acessos de batata-doce utilizando caracteres fenotípicos de raiz. Horticultura Brasileira 30: 595-599.

SUGRI, I; MAALEKUU, BK; GAVEH, E; KUSI, F. 2019. Compositional and shelflife indices of sweet potato are significantly improved by pre-harvest dehaulming. Annals of Agricultural Sciences 64: 113-120.

VARGAS, PF; ENGELKING, EW; FERREIRA, LC; ALVES, E; OLIVEIRA, HC. 2018. Genetic diversity among sweet potato crops cultivated by traditional farmers. Revista Caatinga 31: 779-790

VIZZOTTO, M; PEREIRA, ES; VINHOLES, JR; MUNHOZ, PC; FERRI, NML; CASTRO, LAS; KROLOW, ACR. 2017. Physicochemical and antioxidant capacity analysis of colored sweet potato genotypes: in natura and thermally processed. Ciência Rural 47: e20151385. 